\title{
Inhibitory Factors of Transglutaminase in Salted Salmon Meat Paste
}

\author{
Jianrong Wan, ${ }^{* 1}$ Ikuo Kimura, ${ }^{* 2}$ and Nobuo Seki ${ }^{* 1}$ \\ ${ }^{*}$ Laboratory of Food Biochemistry, Faculty of Fisheries, Hokkaido University, \\ Hakodate, Hokkaido 041, Japan \\ ${ }^{*}$ Central Research Laboratory, Nippon Suisan Kaisha Ltd., \\ Kitano, Hachioji, Tokyo 192, Japan
}

(Received March 2, 1995)

\begin{abstract}
Transglutaminase (TGase) plays an important role in the formation of set gel and subsequent final surimi-based products with greater elasticity and water-holding capacity from salted surimi paste. In salmon surimi paste, however, the enzyme activity was inhibited even in the presence of a sufficient concentration of $\mathrm{Ca}^{2+}$ required for full activation. It was found that water soluble muscle proteins did not inhibit TGase activity, while deproteinized muscle extract markedly inhibited the enzyme activity and depressed TGase-induced cross-linking and gelation of salmon actomyosin.

The deproteinized salmon muscle extract contained a large amount of anserine as a major nitrogen compound. Anserine inhibited TGase activity, but its inhibitory action was slightly lower than that of the muscle extract. However, the reduction of TGase-induced cross-linking of myosin heavy chain and gelation of actomyosin by anserine was in the same extent as that by the muscle extract.
\end{abstract}

Key words: salmon, setting, transglutaminase, anserine

The setting plays an important role to enhance the gel strength and water-holding capacity of final surimi-based products $^{1,2)}$ and has been attributed to the transglutaminase (TGase)-catalyzed polymerization of myosin heavy chains associated with ordered aggregation of muscle proteins. ${ }^{3-6)}$

The use of chum salmon which returns to a river in autumn has been limited as a new resource for surimi, in spite of an abundance and recent low prices in Japan. This is because of inferior gel-forming ability caused by the absence of setting response. ${ }^{6-8)}$ In the preceding paper, ${ }^{6)}$ we demonstrated that the poor gel formability was primarily attributable to low TGase activity in salmon surimi paste and, in addition, caused partly by low concentrations of myosin and $\mathrm{Ca}^{2+}$, compared with walleye pollack surimi. Although salmon actomyosin is characterized as a good substrate for TGase, upon finding the fact that no effect of TGase added into the surimi on the gelation has suggested the existence of some factors inhibiting TGase activity. The objective of the present study was, therefore, to examine and identify the inhibitory factor(s) in salmon surimi.

\section{Materials and Methods}

\section{Materials}

Chum salmon Oncorhynchus keta surimi used in this experiment was of the same lot provided by Hokkaido Gyoren (Hokkaido Fishermen's Association, Sapporo) as described in the preceding paper. ${ }^{6}$ Live salmon were caught off the coast of Hakodate in October, 1993. Monodansylcadaverine (MDC) and anserine were purchased from Sigma, St. Louis, MO. All other chemicals were of analytical grade from Wako Pure Chemical Industries Ltd., Osaka.

\section{Preparation of Proteins}

Actomyosin was prepared from salmon dorsal muscle by the conventional method. ${ }^{9}$ Water soluble protein fraction was prepared as follows: salmon dorsal muscle was homogenized in the 5 volumes of $0.1 \mathrm{M} \mathrm{NaCl}-20 \mathrm{mM}$ Tris$\mathrm{HCl}$ at $\mathrm{pH} 7.5$ and centrifuged at $9,000 \times g$ for $20 \mathrm{~min}$. The supernatant obtained was filled in a dialyzing bag and then it was buried in powdered polyethylene glycol 6,000 at $0^{\circ} \mathrm{C}$ to concentrate the volume to approximately one fifth. The bag was dialyzed against a $50 \mathrm{mM}$ Tris- $\mathrm{HCl}$ buffer at $\mathrm{pH}$ 7.5 and then centrifuged at $100,000 \times g$ for $60 \mathrm{~min}$. The supernatant was used as a water soluble protein fraction.

TGase from carp skeletal muscle and acetylated casein were prepared by the methods as described in the preceding paper. ${ }^{6}$ Protein concentration was determined by the biuret method using bovine serum albumin as standard. ${ }^{10)}$

\section{Preparation of Deproteinized Muscle Extract}

Salmon dorsal muscle $(50 \mathrm{~g})$ was homogenized in the equal volume of water and then $50 \mathrm{ml}$ of $15 \%$ trichloroacetic acid (TCA) was added prior to centrifuge at $10,000 \times g$ for $20 \mathrm{~min}$. To remove the added TCA, $50 \mathrm{ml}$ diethylether was added to the supernatant and vigorously mixed with each other. After the mixture was left to separate into two layers, the water layer was collected. The treatment was repeated six times. The extract was neutralized and centrifuged at $10,000 \times g$ for $20 \mathrm{~min}$. The supernatant obtained was lyophilized.

\section{Determination of Amino Acids and Related Compounds in the Muscle Extract}

The composition of amino acids and related compounds in the muscle extract was analyzed with an amino acid analyzer (Hitachi L-8500; packed column $\$ 2622,4.6 \times 60$ 
$\mathrm{mm})$.

\section{Assay of TGase Activity}

TGase (EC 2.3.2.13) activity was assayed in a reaction mixture containing $2 \mathrm{mg} / \mathrm{ml}$ acetylated casein, $0.55 \mathrm{mM}$ $\mathrm{MDC}, 5 \mathrm{mM} \mathrm{CaCl}_{2}, 5 \mathrm{~mm}$ dithiothreitol, and $50 \mathrm{~mm}$ Tris$\mathrm{HCl}\left(\mathrm{pH} \mathrm{7.5)}\right.$ at $25^{\circ} \mathrm{C}$ for $60 \mathrm{~min}$. After the reaction was terminated by the addition of $5 \%$ TCA at final concentration, the incorporated MDC into acetylated casein was determined according to the method of Kishi et al. ${ }^{11)}$ One unit of TGase activity was defined as the amount of enzyme that catalyzed the incorporation of $1 \mathrm{nmol} \mathrm{MDC}$ into $1 \mathrm{mg}$ acetylated casein for $1 \mathrm{~min}$.

\section{Cross-linking and Gelation of Salmon Actomyosin}

Actomyosin $(5 \mathrm{mg} / \mathrm{ml})$ was incubated with carp TGase $(0.17$ unit $/ \mathrm{ml})$ in a medium containing $0.6 \mathrm{M} \mathrm{NaCl}, 5 \mathrm{~mm}$ $\mathrm{CaCl}_{2}, 5 \mathrm{mM}$ dithiothreitol, and $20 \mathrm{mM}$ Tris- $\mathrm{HCl}$ at $\mathrm{pH}$ 7.5 and $25^{\circ} \mathrm{C}$. The reaction was terminated by heating in boiling water for 2 min. Cross-linking of myosin heavy chain of actomyosin was analyzed by an SDS-PAGE. ${ }^{6}$ The gelation of actomyosin $(8 \mathrm{mg} / \mathrm{ml})$ was demonstrated by the method that tubes containing the reaction mixture ( $2 \mathrm{ml}$ in total) were turned upside down after the incubation at $25^{\circ} \mathrm{C}$ for $3 \mathrm{~h} .{ }^{4)}$

\section{Results}

MDC Incorporation to Surimi and Water Soluble Proteins In order to obtain certain evidence of the presence of an inhibitory factor(s) of TGase in salmon meat and surimi, we began to examine water soluble protein as a possible candidate. Each $(25 \mathrm{mg} / \mathrm{ml})$ of three kinds of salted proteins prepared from salmon surimi, water soluble protein, and cooked water soluble protein, was incubated with TGase $(0.16$ unit $/ \mathrm{m} l)$ in the medium containing $0.6 \mathrm{M}$ $\mathrm{NaCl}, 2.5 \mathrm{mM} \mathrm{MDC}, 5 \mathrm{mM} \mathrm{CaCl}_{2}$, and $50 \mathrm{mM}$ Tris- $\mathrm{HCl}$ (pH 7.5) at $25^{\circ} \mathrm{C}$. The incorporated MDC into each salted protein was determined. Figure 1 shows that the rates of incorporation of MDC were $0.13,0.19$, and $0.28 \mathrm{nmol} /$ $\mathrm{m} l \cdot \mathrm{min}$ for the surimi, water soluble protein, and cooked water soluble protein, respectively. These results indicate that water soluble protein is a better substrate than surimi protein, suggesting no contribution to inhibit TGase activity to any great extent in the surimi paste. Furthermore, since MDC added to salmon surimi paste was incorporated to neither myofibrillar proteins nor water soluble proteins as described previously, ${ }^{6}$ it could be excluded as a possibility that water soluble protein in the surimi paste competitively inhibited the cross-linking of myosin heavy chain during the incubation.

\section{Effect of Muscle Extract on TGase Activity}

The deproteinized muscle extract was prepared from salmon dorsal muscle in place of surimi containing a large amount of sugars and polyphosphates as cryoprotectants which inhibited TGase activity to some extent. TGase activity was depressed by the addition of muscle extract in a concentration dependent manner (Fig. 2); the addition of $1 \mathrm{ml}$ of muscle extract corresponding to $2.5 \mathrm{~g}$ muscle depressed the activity to approximately $20 \%$ of the control. Furthermore, in the presence of muscle extract,

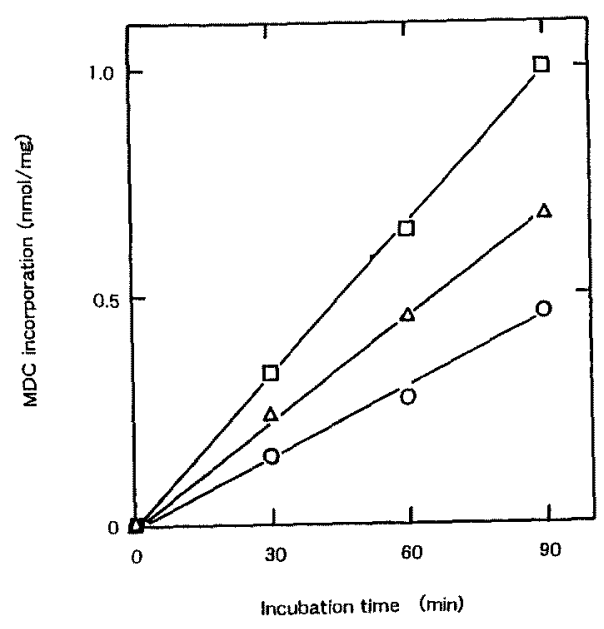

Fig. 1. Incorporation of MDC into surimi and water soluble protein during incubation with TGase.

Each $(25 \mathrm{mg} / \mathrm{ml})$ of salmon surimi $(O)$, water soluble protein $(\triangle)$, and cooked water soluble protein at $100^{\circ} \mathrm{C}$ for $2 \mathrm{~min}(\square)$ was incubated with $2.5 \mathrm{~mm} \mathrm{MDC}$ and $0.16 \mathrm{unit} / \mathrm{m} / \mathrm{TG}$ Ge in the medium containing $5 \mathrm{mM} \mathrm{CaCl}_{2}, 5 \mathrm{mM} \mathrm{DTT}$, and $50 \mathrm{mM}$ Tris-HCl $(\mathrm{pH} 7.5)$ at $25^{\circ} \mathrm{C}$ for up to $90 \mathrm{~min}$.

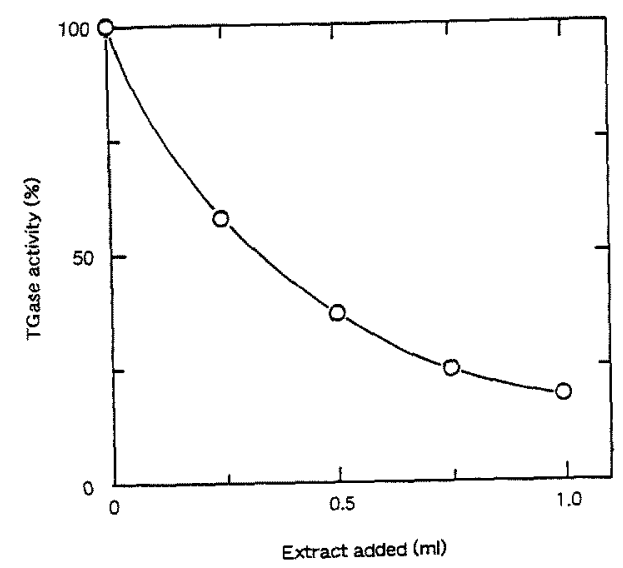

Fig. 2. Effect of deproteinized muscle extract on TGase activity.

TGase activity was assayed in the medium containing $2 \mathrm{mg} / \mathrm{ml}$ acetylated casein, $0.55 \mathrm{mM} \mathrm{MDC}, 5 \mathrm{~mm} \mathrm{CaCl}, 5 \mathrm{~mm}$ DTT, and 50 $\mathrm{mM}$ Tris- $\mathrm{HCl}(\mathrm{pH} 7.5)$ with $0.178 \mathrm{unit} / \mathrm{m} / \mathrm{TGase}$. Various amounts of the extract were added to the medium.

salmon actomyosin incubated with carp TGase was markedly reduced in the rate and extent of cross-linking of myosin heavy chain (Fig. 3). The gelation of actomyosin was also retarded by the addition of muscle extract. Figure 4 shows that rigid actomyosin gel was formed in the absence of muscle extract after the incubation at $25^{\circ} \mathrm{C}$ for $3 \mathrm{~h}$, while the addition of $0.1-0.2 \mathrm{~m} /$ muscle extract resulted in a formation of soft gel and the extract added above $0.4 \mathrm{ml}$ completely inhibited the gelation. These results clearly demonstrate that the deproteinized salmon muscle extract effectively inhibits TGase activity.

\section{Effect of Anserine on TGase Activity}

Amino acids and related compounds in the muscle extract were analyzed in order to determine a compound(s) 


\section{Extract added (ml)}

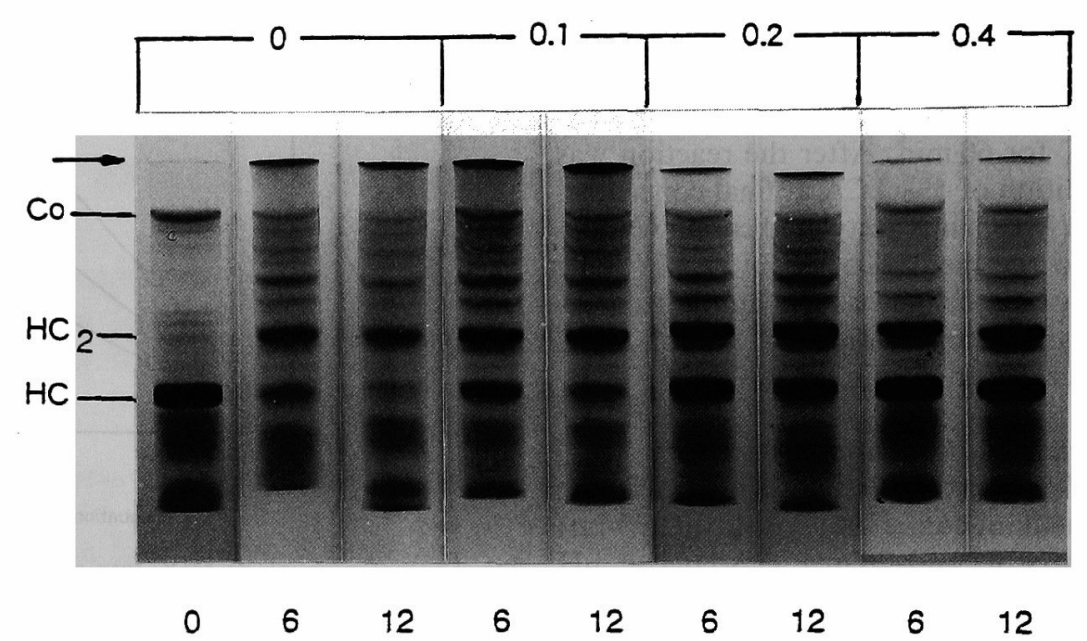

Incubation time (h)

Fig. 3. Effect of the muscle extract on TGase-induced cross-linking of actomyosin.

Salmon actomyosin $(5 \mathrm{mg} / \mathrm{m} l)$ was incubated with $0.17 \mathrm{unit} / \mathrm{m} l$ TGase in the presence of various amounts of deproteinized muscle extract in the medium containing $5 \mathrm{mM} \mathrm{CaCl}_{2}, 5 \mathrm{~mm} \mathrm{DTT}$, and $20 \mathrm{~mm}$ Tris- $\mathrm{HCl}(\mathrm{pH} 7.5)$ at $25^{\circ} \mathrm{C}$. The extract $(1 \mathrm{~m} /)$ was equivalent to $2.5 \mathrm{~g}$ of salmon raw muscle. The arrow indicates the origin of $1.8 \%$-polyacrylamide gels. $\mathrm{HC}$, Myosin heavy chain monomer; $\mathrm{HC}_{2}$, myosin heavy chain dimer; $\mathrm{Co}, \beta$ connectin.

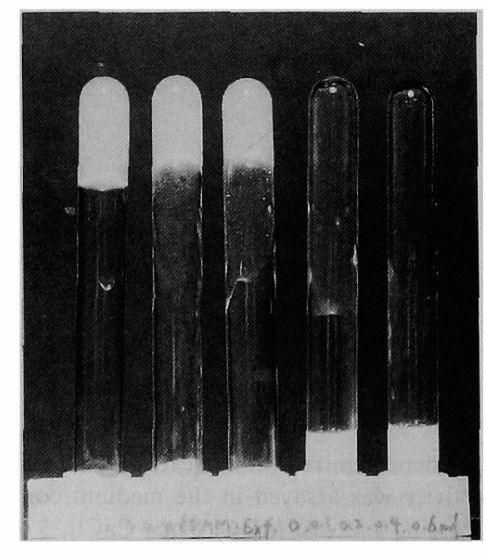

$\begin{array}{lllll}0 & 0.1 & 0.2 & 0.4 & 0.6\end{array}$

\section{Extract added (ml)}

Fig. 4. Effect of the muscle extract on TGase-induced gelation of salmon actomyosin.

The experimental condition was the same as in Fig. 3, except that $8 \mathrm{mg} / \mathrm{m} l$ salmon actomyosin was used. Tubes containing the reaction mixture were turned upside down after $3 \mathrm{~h}$ incubation at $25^{\circ} \mathrm{C}$.

inhibiting TGase activity. Table 1 shows the results; a large amount of anserine was contained in the muscle extract corresponding to $18.5 \mathrm{~mm}$ in the muscle. This characteristic distribution of amino acid and related compounds in salmon muscle extract is consistent with the results reported by Konosu et al. ${ }^{12)}$ The addition of anserine to the TGase assay medium clearly showed a decrease in the en-
Table 1. Major amino acids and related compounds in the extracts of salmon muscle and surimi*

\begin{tabular}{lrrrcc}
\hline & \multicolumn{2}{c}{ Dorsal muscle } & & \multicolumn{2}{c}{ Surimi } \\
\cline { 2 - 3 } \cline { 5 - 6 } & $\mathrm{mg} / 100 \mathrm{~g}$ & $\%$ & & $\mathrm{mg} / 100 \mathrm{~g}$ & $\%$ \\
\hline Glutamic acid & 10.88 & 1.98 & & 2.00 & 2.15 \\
Glycine & 6.68 & 1.22 & & \\
Alanine & 18.80 & 3.42 & & 4.20 & 4.51 \\
Valine & 5.12 & 0.93 & & 4.40 & 4.72 \\
Lysine & 21.68 & 3.95 & & 3.20 & 3.43 \\
Histidine & 4.68 & 0.85 & & \\
Arginine & 4.72 & 0.86 & & 3.60 & 3.86 \\
Ammonia & & & & 5.20 & 5.58 \\
Taurine & 12.04 & 2.19 & & 5.60 & 6.01 \\
Anserine & 444.32 & 80.88 & & 58.20 & 62.45 \\
\hline Total & 549.36 & 100.00 & & 93.20 & 100.00 \\
\hline
\end{tabular}

* Major compounds were listed above $4 \mathrm{mg}$ and $2 \mathrm{mg}$ per $100 \mathrm{~g}$ (wet weight) of dorsal muscle and surimi, respectively.

zyme activity in dose dependent (Fig. 5). Approximately $20 \mathrm{mM}$ anserine decreased the activity to half. Carnosine also inhibited the activity, while $\beta$-alanine, a constituent amino acid of anserine, did not inhibit the activity at all. It was also recognized that anserine inhibited TGase-induced cross-linking of myosin heavy chain and gelation of salmon actomyosin (Figs. 6 and 7). A half time of the decrease in myosin heavy chain became longer from 1.5 to 3 and $17 \mathrm{~h}$ by the addition of 5 and $20 \mathrm{~mm}$ anserine, respectively (Fig. 6, upper panels). SDS-PAGE revealed that a highly polymerized myosin heavy chain, remaining on the top of acrylamide gel was hardly formed in the presence of anserine above $5 \mathrm{~mm}$ (Fig. 6, lower panels). Figure 7 shows 
that the gelation of actomyosin was partly and completely inhibited by the addition of anserine at 5 and above 10 $\mathrm{mM}$, respectively.

\section{Discussion}

As reported in the preceding paper, ${ }^{6}$ a major cause of the absence of setting response in salmon surimi paste is a low level of TGase activity. In addition, low concentrations of myosin and $\mathrm{Ca}^{2+}$ partly bring about the inferior ge-

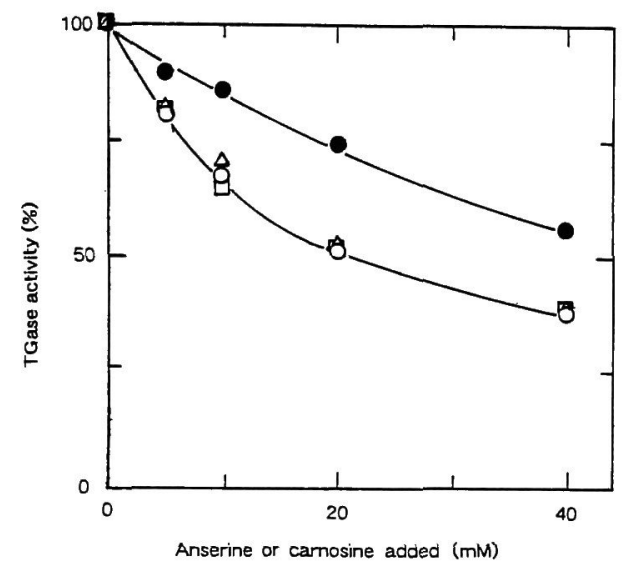

Fig. 5. Effect of anserine on TGase activity.

TGase activity was assayed in the medium containing $2 \mathrm{mg} / \mathrm{m} l$ acetylated casein, $0.55 \mathrm{~mm} \mathrm{MDC,} 5 \mathrm{mM} \mathrm{CaCl}_{2}, 5 \mathrm{mM}$ DTT, and 50 $\mathrm{mM}$ Tris- $\mathrm{HCl}(\mathrm{pH}$ 7.5) with TGase. Various amounts of anserine (open symbols) or carnosine (closed symbols) were added to the assay mixture. $\bigcirc \bullet$, With 0.16 unit $/ \mathrm{m} l$ TGase; $\triangle$, with 0.08 unit $/ \mathrm{m} l$ TGase; $\square$, with 0.04 unit $/ \mathrm{m} l$ TGase. lation of salmon surimi paste. However, a finding that the addition of carp TGase to the surimi paste enhanced neither TGase activity nor the polymerization of surimi proteins allowed to suppose the presence of an inhibitory factor(s) of TGase. ${ }^{6}$ In this study, we found that the factor exists in the deproteinized muscle extract and identified it as anserine. It was a major component in salmon muscle extract and inhibited not only TGase activity but also cross-linking and gelation of actomyosin. Since salmon

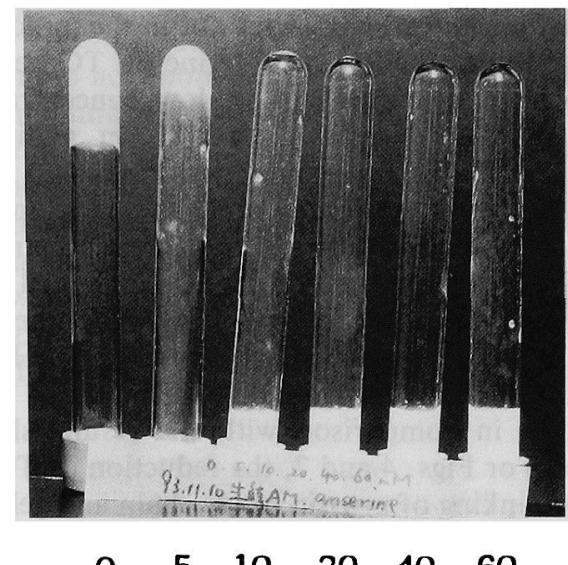

\section{Anserine added ( $\mathrm{mM})$}

Fig. 7. Effect of anserine on TGase-induced gelation of salmon actomyosin.

Experimental conditions were the same as in Fig. 4, except that the deproteinized muscle extract was replaced by anserine. The amount of anserine added to the reaction mixture is indicated in the figure.

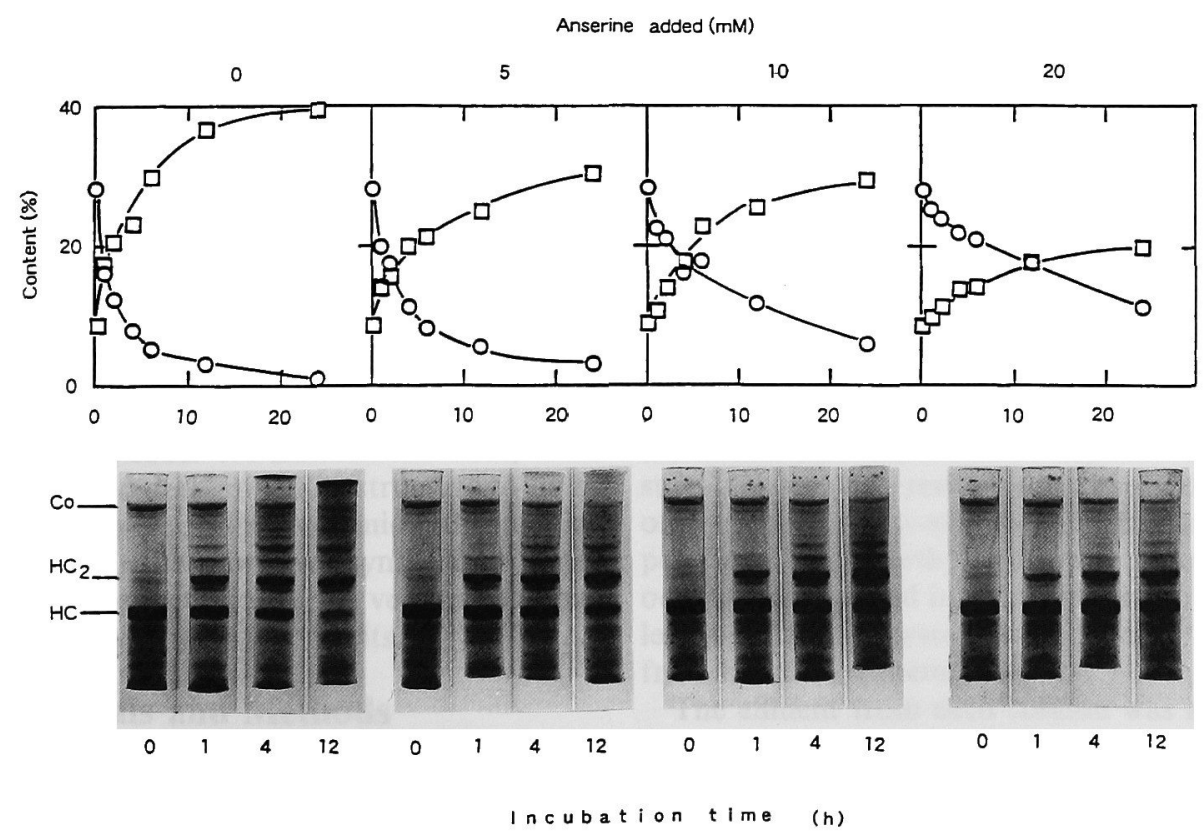

Fig. 6. Effect of anserine on TGase-induced cross-linking of actomyosin.

The experimental conditions were the same as described in Fig. 3, except that the deproteinized muscle extract was replaced by anserine. The amount of anserine added to the reaction mixture is indicated above the upper panels. $\bigcirc$, Myosin heavy chain; $\square$, myosin heavy chain polymers. Lower panels show the SDS-PAGE patterns. HC, Myosin heavy chain monomer; $\mathrm{HC}_{2}$, myosin heavy chain dimer; Co, $\beta$-connectin. 
muscle contains a large amount of anserine, approximately $20 \mathrm{mM}$, it may cause the inferior gelation of salmon meat paste as a result of TGase inhibition, even if TGase is added to the meat paste. According to the reports by Suyama et al. ${ }^{13,14)}$ some fish belonging to mackerels and billfishes, such as yellowfin tuna, bluefin tuna, little tuna, skipjack, and black marlin also contain a large amount of anserine in their muscles as well as salmonids fish. ${ }^{12,15)}$ The facts provide a new interest in the effect of anserine on setting of their salted minced meats, because all these fish belong to a difficult setting group. ${ }^{16)}$

In the salmon surimi paste, but not in the minced meat paste, the inhibitory effect of anserine on TGase activity should be reduced because of its low concentration of $58.20 \mathrm{mg} / 100 \mathrm{~g}$ or $2.4 \mathrm{mM}$ (Table 1). In addition, as shown in Fig. 5, TGase activity was decreased to $50 \%$ upon adding $20 \mathrm{~mm}$ anserine, while the same inhibition was attained by the addition of $0.3 \mathrm{~m} l$ muscle extract containing $6.9 \mathrm{~mm}$ anserine. It is therefore suggested that the deproteinized muscle extract must contain another inhibitory factor(s) of TGase together with anserine. However, we cannot find a possible candidate in the list of Table 1. Furthermore, in comparison with the results shown in Figs. 3 and 6 or Figs. 4 and 7, the reduction of TGase-induced cross-linking of myosin heavy chain and gelation of salmon actomyosin by the deproteinized muscle extract was the same as that by anserine of an equal amount in the muscle extract; for example, $0.2 \mathrm{~m} l$ muscle extract and its equivalent amount of anserine ( $5 \mathrm{~mm})$ showed the same effect on the reduction of cross-linking and gelation of actomyosin.

On the deletion of TGase activity in salmon surimi paste, $2.4 \mathrm{~mm}$ anserine in the surimi is slightly low in the concentration required for complete inhibition of crosslinking of myosin heavy chain and gelation of actomyosin (Figs. 6 and 7). In relation to the deletion of TGase activity, we cannot completely exclude the possibility of proteolytic degradation of TGase in addition to the presence of $2.4 \mathrm{~mm}$ anserine. As reported in the preceding paper, ${ }^{6}$ although the use of a protease inhibitor, E-64, to salmon surimi paste effectively inhibits the proteolytic degradation of myosin heavy chain, it remains unclear whether E-64 is also effective on the proteolysis of TGase.

\section{References}

1) T. Suzuki: Fish and krill protein: processing technology, 1st ed., Applied Science Publishers, London, 1981, pp. 62-114.

2) A. P. Stone and D. W. Stanley: Mechanisms of fish muscle gelation. Food Res. Int., 25, 381-388 (1992).

3) N. Seki, H. Uno, N.-H. Lee, 1. Kimura, K. Toyoda, T. Fujita, and K. Arai: Transglutaminase activity in Alaska pollack muscle and surimi, and its reaction with myosin B. Nippon Suisan Gakkaishi, 56, 125-132 (1990).

4) 1. Kimura, M. Sugimoto, K. Toyoda, N. Seki, K. Arai, and T. Fujita: A study on the cross-linking reaction of myosin in kamaboko "suwari" gels. Nippon Suisan Gakkaishi, 57, 1389-1396 (1991).

5) J. Wan, I. Kimura, M. Satake, and N. Seki: Effect of calcium ion concentration on the gelling properties and transglutaminase activity of walleye pollack surimi paste. Fisheries Sci., 60, 107-113 (1994).

6) J. Wan, I. Kimura, M. Satake, and N. Seki: Causes of inferior gelforming ability of salmon surimi paste. Fisheries Sci., 61, 711-715 (1995).

7) S. Nishimoto, A. Hashimoto, N. Seki, and K. Arai: Setting of mixed salted meat paste of two fish species in relation to cross-linking reaction of myosin heavy chain. Nippon Suisan Gakkaishi, 54, 1227-1235 (1988).

8) H. Saeki, Z. Iseya, S. Sugiura, and N. Seki: Gel-forming characteristics of frozen surimi from chum salmon in the presence of protease inhibitors. J. Food Sci., 60, 917-921, 928 (1995).

9) R. Takashi, K. Arai, and T. Saito: Studies on muscular proteins of fish II. Preparation of actomyosin from carp muscle. Nippon Suisan Gakkaishi, 36, 169-172 (1970).

10) A. G. Gornall, C. J. Bardawill, and M. M. David: Determination of serum proteins by means of the biuret reaction. J. Biol. Chem., 177, 751-765 (1949).

11) H. Kishi, H. Nozawa, and N. Seki: Reactivity of muscle transglutaminase on carp myofibrils and myosin B. Nippon Suisan Gakkaishi, 57, 1203-1210 (1991).

12) S. Konosu, K. Yamaguchi, S. Fuke, and T. Shirai: Amino acids and related compounds in the extracts of different parts of the muscle of chum salmon. Nippon Suisan Gakkaishi, 49, 301-304 (1983).

13) M. Suyama, T. Suzuki, M. Maruyama, and K. Saito: Determination of carnosine, anserine, and balenine in the muscle of animal. Nippon Suisan Gakkaishi, 36, 1048-1053 (1970).

14) M. Suyama and Y. Yoshizawa: Free amino acid composition of the skeletal muscle of migratory fish. Nippon Suisan Gakkaishi, 39, 1339-1343 (1973).

15) T. Shirai, S. Fuke, Y. Yamaguchi, and S. Konosu: Studies on ex tractive components of salmonids-11. Comparison of amino acids and related compounds in the muscle extracts of four species of salmon. Comp. Biochem. Physiol., 74B, 685-689 (1989).

16) Y. Shimizu, R. Machida, and S. Takenami: Species variations in the gel-forming characteristics of fish meat paste. Nippon Suisan Gakkaishi, 41, 95-104 (1981). 